\title{
Analysis of Physicochemical Parameters and Screening of Microorganisms to Formulate Ferments from Oil Palm Sap (Elaeis guineensis) in the Korhogo Area
}

\section{Karamoko Detto $^{1 *}$, Moroh Jean-Luc Aboya ${ }^{1}$, Kokora Aya Philomène ${ }^{1}$, Kouaho Frederic Harding ${ }^{1}$ and Dje Koffi Marcellin ${ }^{2}$}

\author{
${ }^{1}$ Department of Biochemistry and Genetics, Laboratory of Food Microbiology and \\ Biotechnology, University Peleforo Gon Coulibaly, Korhogo, Côte d'Ivoire \\ ${ }^{2}$ Department of Food Sciences and Technology, University Nangui Abrogoua, \\ Abidjan, Cote d'Ivoire \\ *Corresponding author
}

\begin{tabular}{|c|c|}
\hline & A B S T R A C T \\
\hline Keywords & \multirow{4}{*}{$\begin{array}{l}\text { The aim of this study is to select ferments from microorganisms isolated in palm wine to } \\
\text { varieties of palm oil (Dura and Pisifera). The load of mesophilic aerobic germs and yeasts } \\
\text { remains high during tapping of palm wine. The load of Lactic acid bacteria increased in } \\
\text { Pisifera variety to log } 1.4 \pm 0.1 \mathrm{CFU} / \mathrm{ml} \text { for the first day at log } 2.9 \pm 0.1 \mathrm{CFU} / \mathrm{ml} \text { after two } \\
\text { weeks and then decrease after the last week at log } 0.6 \pm 0.1 \mathrm{CFU} / \mathrm{ml} \text {. In the Dura palm } \\
\text { wine, this load increased from log } 0.9 \pm 0.1 \mathrm{CFU} / \mathrm{ml} \text { to } \log 2.2 \pm 0.2 \mathrm{CFU} / \mathrm{ml} \text { after two } \\
\text { weeks. However, Gram strain showed the presence of Gram-positive and Gram-negative } \\
\text { bacteria in Dura and Pisifera palm sap during tapping. The coccobacilli, cocci and bacilli } \\
\text { were identified in both types of palm wine. The sap of the Dura and Pisifera varieties } \\
\text { contains a high-level sugars content (total and reducing) at the beginning of the operation. } \\
\text { During heat treatment, sugars and vitanin C decrease while microorganisms disappear after } \\
3 \text { minute. The panel carried after fermentation out in the laboratory, allowed to obtain } 5 \\
\text { ferments from microorganisms isolated from palm wine. }\end{array}$} \\
\hline $\begin{array}{l}\text { Palm wine, } \\
\text { Ferments, Heat } \\
\text { treatment, } \\
\text { Microorganisms }\end{array}$ & \\
\hline Article Info & \\
\hline $\begin{array}{l}\text { Accepted: } \\
25 \text { July } 2019 \\
\text { Available Online: } \\
10 \text { August } 2019\end{array}$ & \\
\hline
\end{tabular}

\section{Introduction}

Palm-wine is an alcoholic beverage obtained from the fermentation of the sugary sap of various palm species such as the oil palm (Elaeis guineensis), coconut palm (Cocus nucifera), date palm (Phoenix dactylifera), nipa palm (Nypa fruticans), kithul palm (Caryota urens), ron palm (Borassus aethiopum) and raffia palm (Raphia hookeri).
This is commonly called "mimbo" in Cameroon, "nsafufuo" in Ghana, emu" and "oguro" in western part of Nigeria and "bandji" in Côte d'Ivoire (Karamoko et al., 2016; Danmadami et al., 2017). The sap of the palm trees is originally sweet and serves as a rich substrate for the growth of various types of microorganisms (Amoa-Awua et al., 2007; Naknean et al., 2010). The sap undergoes spontaneous or wild fermentation 
which promotes the proliferation of yeasts and bacteria that bring about the conversion of the sweet substrate into several metabolites such as ethanol, lactic acid and acetic acid (Stringini et al., 2009; Santiago-Urbina et al., 2013). There arediverse ways of tapping palm trees; they depend on the locality; but in general, two methods are practiced: in the first method the sap is obtained from a live standing tree, such as the Bandji and Toddy production, this process implicates climbing very tall palm trees, and perforate the trunk in the top of the tree for Bandji production (Ouoba et al., 2012), or cutting into the end of spadix from the tender inflorescence of the palm tree (inflorescence tapping) for Toddy production. In the second method the tree is felled or cut down before tapping (stem tapping), such as palm wine from Ghana and Taberna production (Santiago-Urbina et al., 2013; kouchade et al., 2017).

Palm wine can be consumed in places of ceremonies or particular who come get them on extraction sites. Much of the daily extraction is transported to nearby markets to supply some city pubs and ethanol production. Generally in rural areas, villagers have always shot a box of palme wine and 'bled' to have 'palm wine' to offer guests. However, many issues related to different aspects of traditional food fermentation processes have been identified (kouchade et al., 2017; Karamoko et al., 2016). In addition, few published studies on the parameters of fermentations of palm sap have been reported, and even none on the formulation of a ferment from fermentative microorganisms. As the sap of palm plays an important role in the customary practices in Africa, it is important that microbiology and biochemistry of the fermentation process are well understood.Thus, this work was carried out in order to analyze the physicochemical parameters and screening of fermentative microorganisms of palm oil sap from
Korhogo (North of Ivory Coast) for the formulation of ferments.

\section{Materials and Methods}

\section{Materials and sampling}

Palm wine samples were obtained during the tapping of 20 palm trees (E. guineensis) of two varieties (Dura and Pisifera) at the University Peleforo Gon Coulibaly (Côte d'Ivoire) over a period of 5 months. Collection of palm wine during tapping was normally done twice a day by the tapper, but in this study samples were collected at seven day intervals each morning of sampling day at 7:00 AM in stomacher bags from the beginning until the end of tapping. These samples were immediatelytransported to the laboratory for analyses, carried out in replicates

\section{Determination of total and reducing sugars}

Total sugars in palm wine samples were determined using phenol sulphuric acid method according to Dubois et al., (1956) while reducing sugars were quantified as previously described by Bernfeld (1955). Two independent measurementswere made on each sample and results were expressed in $\mathrm{g} / \mathrm{l}$.

\section{Enumeration of microorganisms}

The palm wine samples were shaken by hand in the stomacher bag and tenfold serial dilutions were prepared and spreadplated for determination of micro-organism counts. After dilutions, enumeration of total aerobic mesophile was carried out using plates of Plate Count Agar (PCA, Difco 0479-17-3; Difco Laboratories, Detroit, MI, USA) which were incubated at $30^{\circ} \mathrm{C}$ for 2 days. Lactic acid bacteria (gram positive catalase negative rods, cocci and coccoids) were enumerated by pour plate on DeMan, Rogosa and Sharpe Agar 
(MRS, Merck 10660; Merck KGaA, Darmstadt, Germany) containing $10 \mathrm{mg} \mathrm{mL}^{-1}$ cycloheximide (ICN 100183 Biomedical Inc., Aurora, $\mathrm{OH}, \mathrm{USA})$ to suppress yeast growth after incubation at $30^{\circ} \mathrm{C}$ for 3 days in an anaerobic jar with anaerocult A (Merck). Yeasts and moulds were enumerated on plates of Sabouraud Chloramphenicol agar (BIORAD, France) which were incubated at $30^{\circ} \mathrm{C}$ for 3-5 days.

\section{Statistical analysis}

The data obtained were subjected to analysis of variance (Statistica, 99 Edition, Alabama, USA) and mean differences determined by Duncan's multiple range tests. Significance of variations in the analyzed data was tested at $95 \%$ confidence limit.

\section{Results and Discussion}

Table 1shows values of microbial parameters obtained in palm wine every day during tapping of two varieties of oil palm trees (Dura and Pisifera). The load in Mesophilic aerobic germs remains high throughout the operating period. The different microorganisms observed show significant differences ( $\mathrm{P}<5 \%$ ) within each type of wine from one week to another. The Mesophilic aerobic germs load is higher in Dura palm sap than in Pisifera sap during operation. At the beginning of the operation, the load is log 6.9 $\pm 0.2 \mathrm{CFU} / \mathrm{ml}$ in Dura wine while it is log $6.5 \pm 0.2 \mathrm{CFU} / \mathrm{ml}$ in that of Pisifera. The yeast load evolves gradually from one week to another in both wines. It goes from $\log 2.1$ $\pm 0.1 \mathrm{CFU} / \mathrm{ml}$ to $\log 4.2 \pm 0.2 \mathrm{CFU} / \mathrm{ml}$ for Pisifera wine. While the lactic acid bacteria load increases from the beginning to the third week in Dura palm wine, it increases and then decreases in that of Pisifera. This log load was $1.4 \pm 0.1 \mathrm{CFU} / \mathrm{ml}$ at $\log 2.9 \pm 0.2 \mathrm{CFU} / \mathrm{ml}$ at week 2 and then reached $\log 0.6 \pm 0.1 \mathrm{CFU}$ / $\mathrm{mL}$ after 21 dyas of tapping. The microorganisms in fresh palm wine might have originated from those that colonize those parts of the palm stalk of the male inflorescence, the leaf petiole, the felt (afabric-like outgrowth of the frond petiole used to cover the tapping hole), the cross strips and xylem stream which are covered with fluffy hairy outgrowths. These results are in agreement with those obtained by Karamoko et al., (2012). According to them, mesophilic aerobic germs obtained in palm wine are brought by the tapper, tapping materials and insects attracted by the sap sugar in the palm wine and microorganisms of the environment. Also, the microbiological study conducted by Ukhum et al., (2005) on palm wine has shown that it contains mesophilic aerobic germs, lactic acid bacteria, yeasts and molds, enterococci and coliforms. The presence of lactic acid bacteria in various palm wines has a beneficial effect on health because they have inhibitory properties against pathogenic and undesirable flora of food. However, lactic acid bacteria in wine convert sugars into organic acids and alcohol (Naknean et al., 2010). The yeast load increases gradually during the exploitation of palm wine and reaches its maximum value in palm wine of the third week for Dura sap. This evolution could be explained by the presence of insects attracted by the high sugar content in palm wine at the end of exploitation. The high load of yeasts in both types of palm wine shows that palm wine produces a large quantity of organic acid; which would promote fermentation and allow the production of ethanol. The organic acids that support the activity of palm wine come mainly from the degradation of palm wine sugars. Because of the presence of living microorganisms in palm wine, its sweet and pleasant taste is quickly lost and replaced by the acidity produced by the action of lactic acid bacteria and yeasts. Also, the abundance of nutrients such as amino acids, vitamins and sugars, palm sap, allow the growth of many 
species of yeasts and bacteria. These results are similar to those of Awasum (2012). According to him, after 48 hours of storage, the $\mathrm{pH}$ in palm wine reaches its minimum value (about 3.5 to 4 ) and its concentration in ethanol is maximum. Thus, only the acidophilic microflora that is resistant to ethanol levels can remain. And this flora mainly consists of yeasts of the genus Saccharomyces and bacteria belonging to Streptococcus, Leuconostoc. The macroscopic observations of the different palm wines at the level of the two varieties of palms made it possible to understand that the wines have almost the same characteristics but with different proportions. Microscopic observations after Gram stain of the mesophilic aerobic germs gave the proportions of $13 \%$ and $87 \%$ respectively for Gram-negative and Gram-positive for Pisifera palm wine and a single color (Gram-positive) or $100 \%$ for Dura palm wine. In the $87 \%$ of the $\mathrm{BG}+$, for the Pisifera palm wine, $29 \%$ of the strains are coccci; $18 \%$ of the strains are coccobacilli and $53 \%$ of the strains are bacilli while in the $13 \%$ of BG- the strains are $100 \%$ of bacilli. In the $100 \% \mathrm{BG}+$, for Dura wine, $50 \%$ of the strains are cocci; $18.75 \%$ strains are coccobacilli and $31.25 \%$ strains are bacilli (Fig. 1). Microscopic observation of lactic acid bacteria presented $100 \%$ positive Gram for Pisifera and Dura palm wines. For Pisiferapalm sap, $90.62 \%$ of the strains are cocci and $9.37 \%$ strains are coccobacilli. In Dura palm sap, $75 \%$ of the strains are cocci and $25 \%$ of the strains are bacilli (Fig. 2). The presence of bacilli in both types of palm wine would indicate the presence of microorganisms of the genus Bacillus. These results are consistent with the work done by Tapsoba et al., (2011). According to them the strains isolated in the palm wine in the form of bacilli are of the genus Bacillus. They also isolated palm wine, a thermophilic and amylolytic bacterium affiliated with the genus
Bacillus. Gram-positive and Gram-negative bacteria have been observed in the palm sap Dura and Pisifera during the production of palm wine. The high percentage of Gram positive bacteria in Dura palm wine would indicate that during the fermentation of palm wine, only Gram positive were responsable of this fermentation. During the heat treatment, a slight decrease is observed in the control (T0min) $(1 \mathrm{~g} / \mathrm{L})$ up to 5 minutes of heat treatment (T5min) $(0.78 \mathrm{~g} / \mathrm{L})$ (Fig. 3). But, from the sixth minute of heat treatment (T6min) heat acts on vitamin $\mathrm{C}$ and it decreases sharply to reach $0.5 \mathrm{~g} / \mathrm{L}$ after 8 minutes of heat treatment and then becomes stable until the end of sterilization. It's results are not in agreement with those of Mehedi, (2018), according to him vitamin C decreases gradually until $15 \mathrm{~min}$ at $120^{\circ} \mathrm{C}$.

The heat treatment for the stabilization of palm sap could have an impact on certain compounds present in this sap.This study revealed a decrease in the rate of the two different types of sugar as a function of the heat treatment time. Thus, the levels of reducing sugars and total sugars drop by $3 \%$ when the sap is sterilized for 2 minutes. However, from 3 to 7 minutes, there is a slight drop variation ranging from $6 \%$ to $13.5 \%$ for reducing sugars and from $5 \%$ to $15 \%$ for total sugars during heat treatment of palm sap. After 7 minutes, there is a sharp decrease.The remaining levels of reducing sugars increase to $42 \%$ and for total sugars, the remaining rate is $60 \%$ and deviates steadily until the end of the heat treatments (Fig. 4). Figure 5 shows the percentage survival of the microorganisms after the heat treatment. Percentages of microorganism survival ranged from $100 \%$ at the control (T0 min) to $50 \%$ after 2 minutes of heat treatment (T2min). But after 2 minutes, a total absence of microorganisms is observed until the end of the heat treatment. 
Table.1 Microorganisms obtained in palm in every day during tapping of two varieties of palm oil trees $\left(\log 10 \mathrm{CFU} / \mathrm{ml}^{-1}\right)$

\begin{tabular}{|c|c|c|c|c|c|}
\hline \multirow[b]{2}{*}{ Varieties } & \multicolumn{5}{|c|}{ Days of sappling } \\
\hline & & 1 & 7 & 14 & 21 \\
\hline \multirow[t]{3}{*}{ Dura } & $\begin{array}{c}\text { Mesophilic } \\
\text { aerobic germs }\end{array}$ & $6,9 \pm 0,2^{a}$ & $6,4 \pm 0,2^{a}$ & $6,50 \pm 0,2^{a}$ & $6,3 \pm 0,2^{a}$ \\
\hline & $\begin{array}{c}\text { Lactic acid } \\
\text { bacteria }\end{array}$ & $0,9 \pm 0,1^{\mathrm{c}}$ & $1,6 \pm 0,1^{\mathrm{c}}$ & $1,4 \pm 0,1^{c}$ & $2,2 \pm 0,2^{b}$ \\
\hline & Yeasts & $3,2 \pm 0,2^{b}$ & $3,8 \pm 0,2^{b}$ & $4,3 \pm 0,2^{b}$ & $4,5 \pm 0,2^{b}$ \\
\hline \multirow[t]{3}{*}{ Pisifera } & $\begin{array}{c}\text { Mesophilic } \\
\text { aerobic germs }\end{array}$ & $6,5 \pm 0,2^{a}$ & $5,9 \pm 0,2^{a}$ & $6,4 \pm 0,2^{a}$ & $5,7 \pm 0,2^{a}$ \\
\hline & $\begin{array}{c}\text { Lactic acid } \\
\text { bacteria }\end{array}$ & $1,4 \pm 0,1^{\mathrm{c}}$ & $2,1 \pm 0,1^{b}$ & $2,9 \pm 0,2^{b}$ & $0,6 \pm 0,1^{\mathrm{c}}$ \\
\hline & Yeasts & $2,1 \pm 0,1^{b}$ & $2,9 \pm 0,2^{b}$ & $3,8 \pm 0,1^{b}$ & $4,2 \pm 0,2^{b}$ \\
\hline
\end{tabular}

$\mathrm{a}, \mathrm{b}, \mathrm{c}$ superscript have level of significance. Similar subscript means no significance difference while different subscript means significant differences

Fig.1 Proportions of mesophilic aerobic germsafter Gram stain: (a) Pisifera sap BG +, (b): Pisifera sap BG- and (c): Dura sap

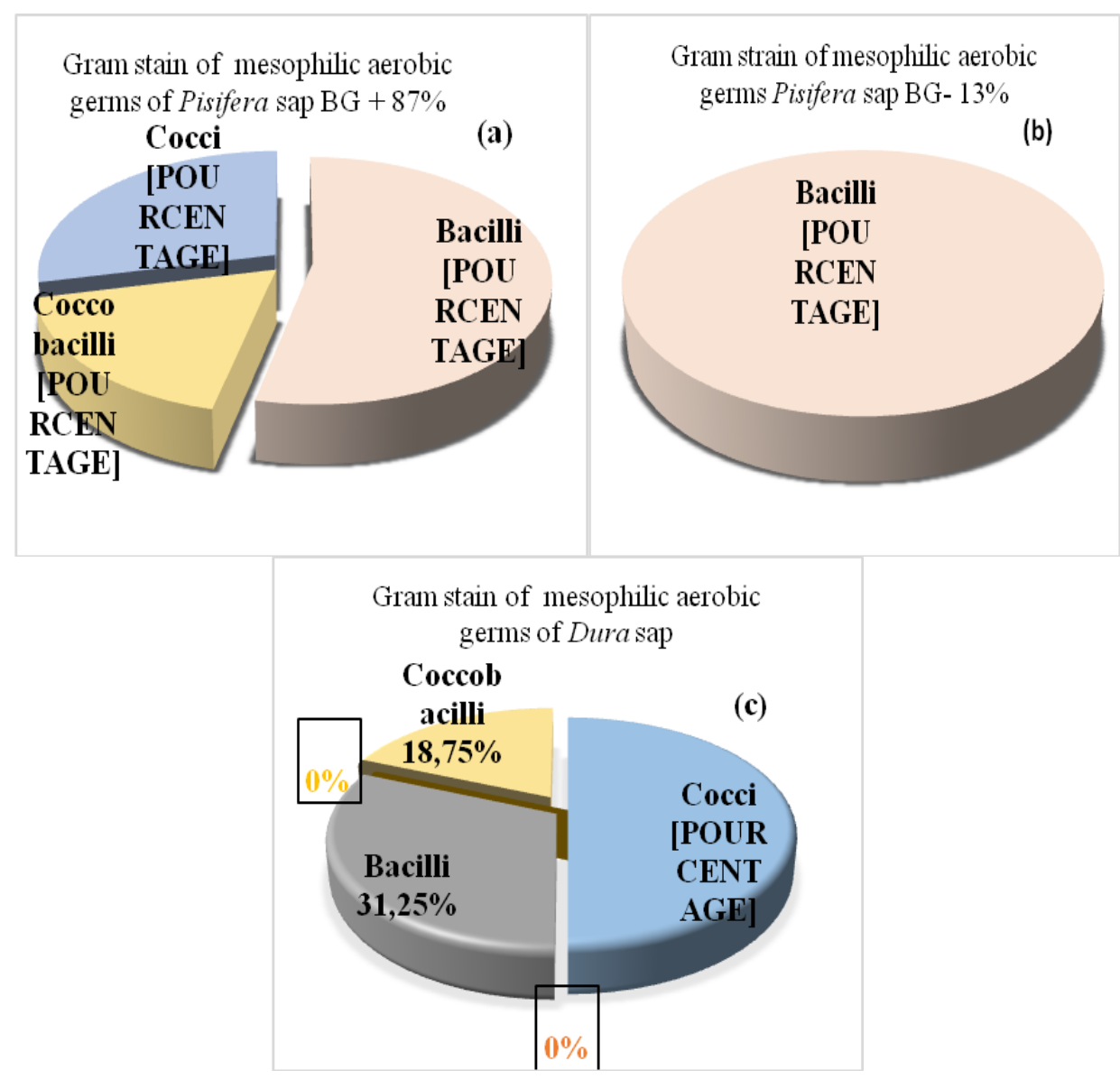


Fig.2 Proportions of lactic acid bacteria after Gram stain: (a) Pisifera sap and (b): Dura sap

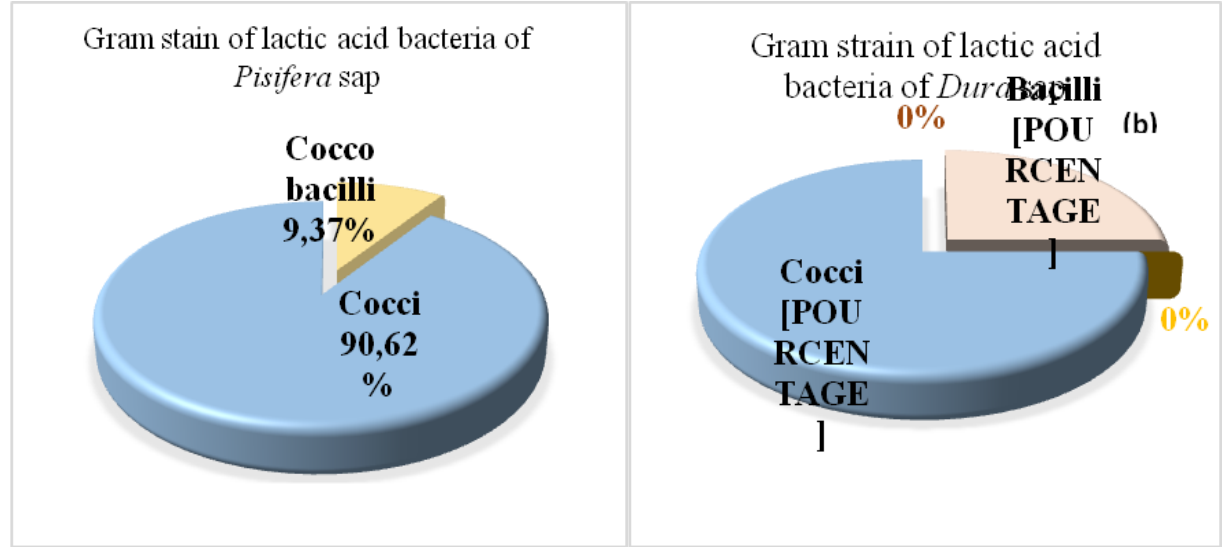

Fig3 Change in Vitamin $\mathrm{C}$ in palm sap during exposure to moist heat

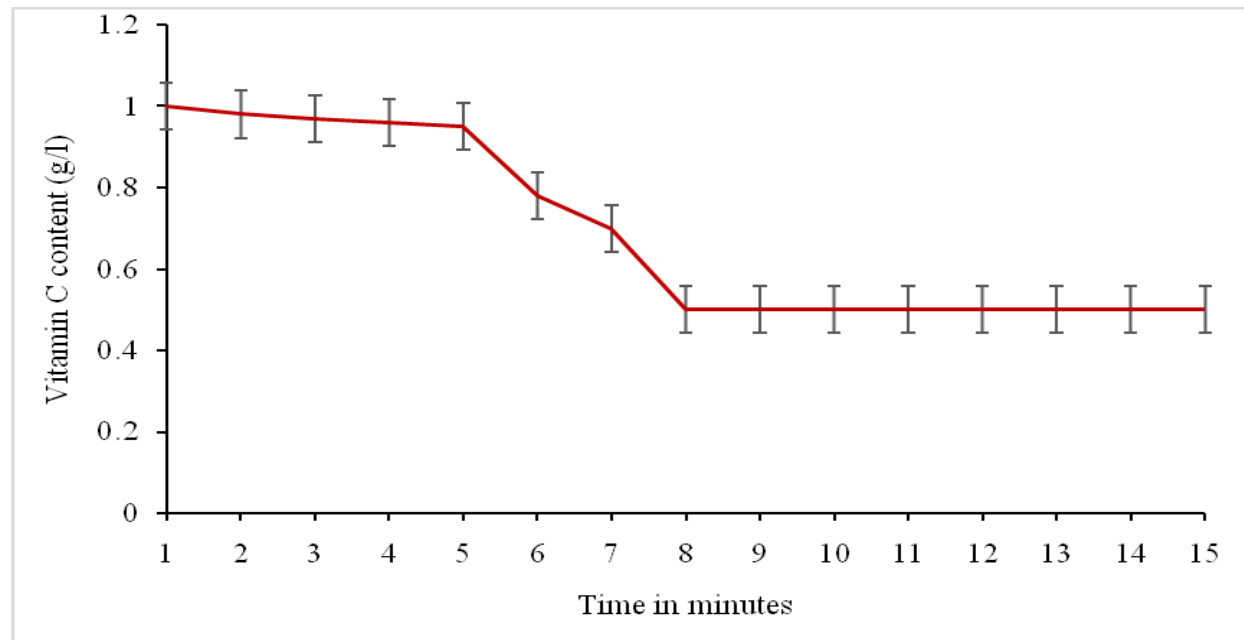

Fig.4 Change in Total and reducing sugars in palm sap during exposure to moist heat

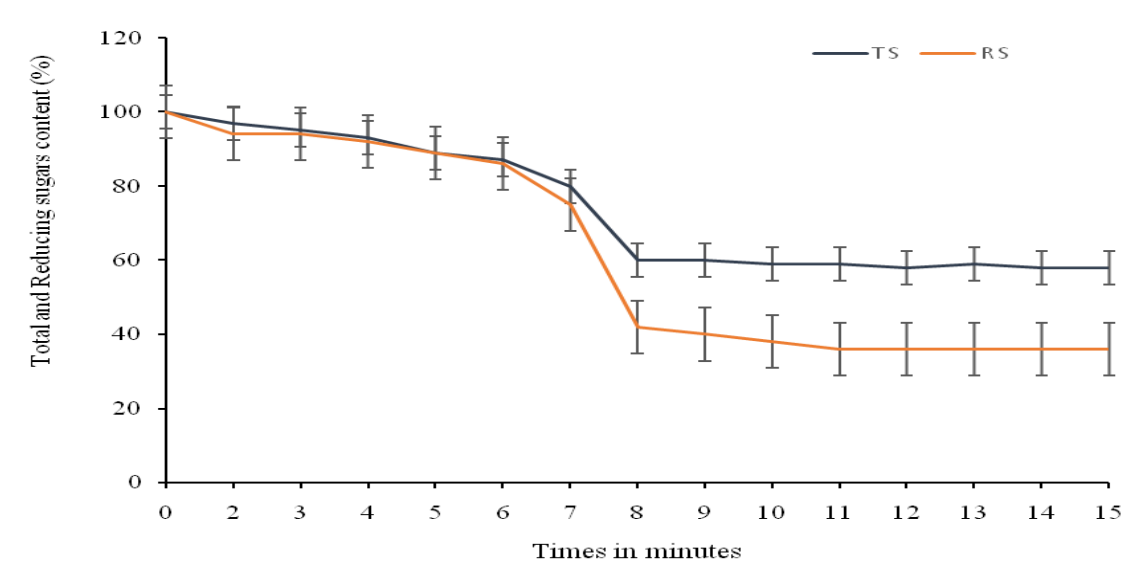


Fig.5 Change in Total microbial count in palm sap during exposure to moist heat

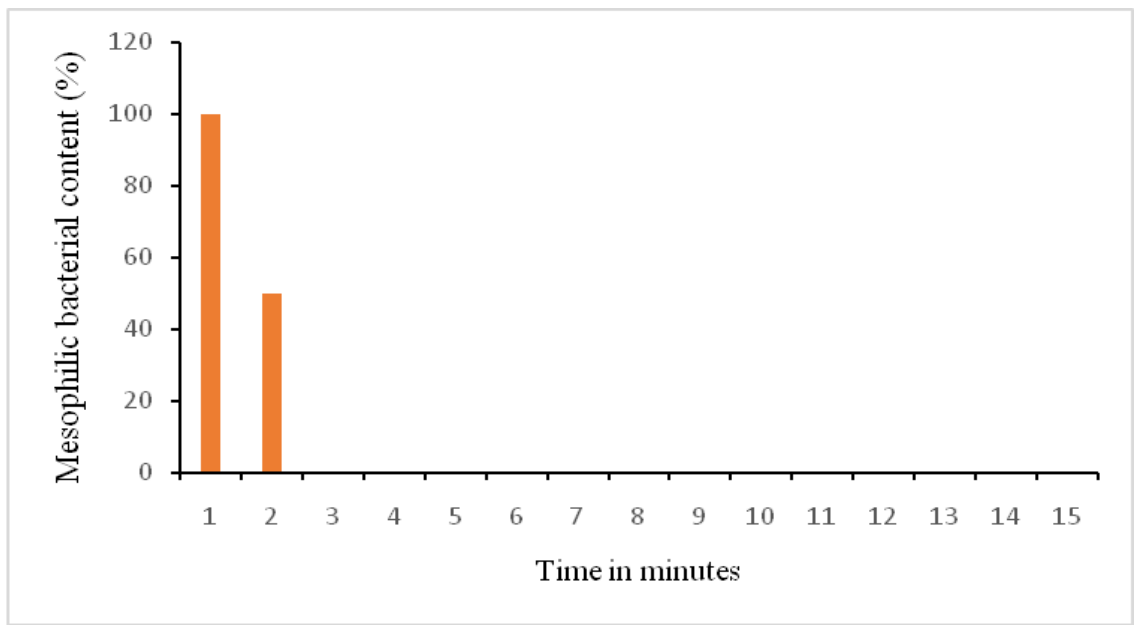

Fig.6 Sensory analysis in palm sap produced using differents microorganisms

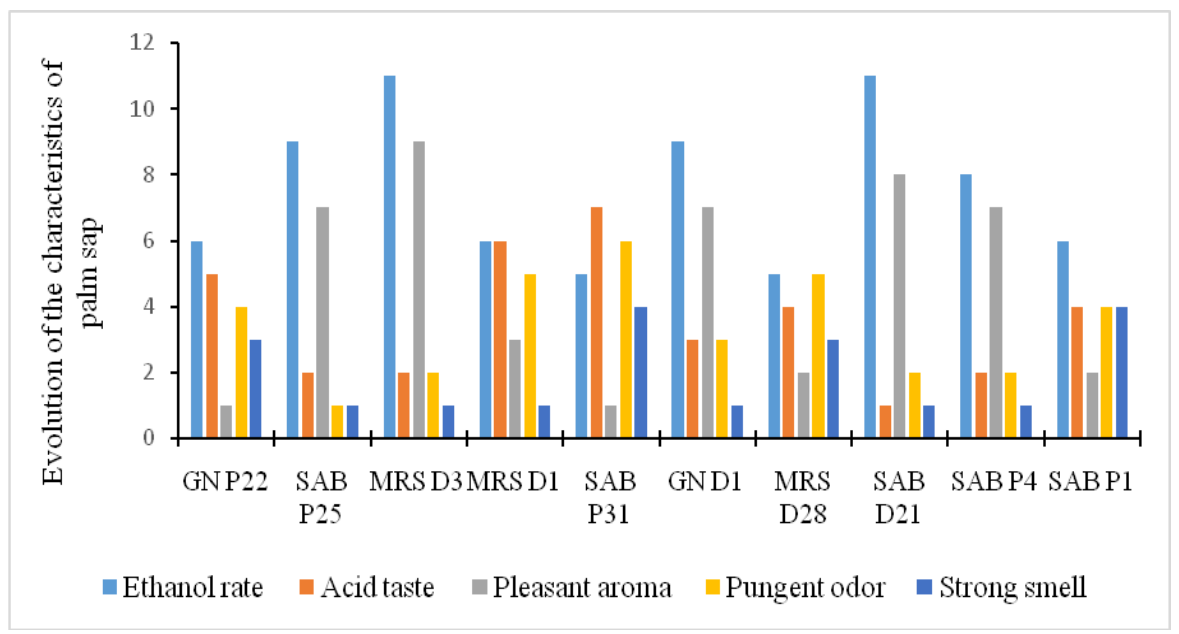

The microbial loads of palm wine decrease with increasing heat treatment time. The microbial loads obtained after inoculation on agar with the same samples are 4.104 CFU / $\mathrm{mL}$ and $44 \mathrm{CFU} / \mathrm{mL}$ respectively for the control (T0min) and 2 minutes of treatment. From the 3rd min of treatment no microorganism is observed in the different sterilized wines. The temperature used for heat treatment of palm wine is a treatment aimed at destroying pathogenic microorganisms and reducing the burden of common microflora or vegetative forms. Processing time plays an important role in removing the microflora from palm wine. The total elimination of the microorganisms after 3 minutes would explain that 3 minutes is the ideal sterilization time of the palm wine.

After 24 hours of fermentation the organized panel allowed to select 5 tubes. Thus, 5 tubes with the right characteristics were identified as better ferments; these are SAB D21 tubes; MRS D3; SAB P4; GN D1 and SAB P25 (Fig. 6). These different saps have the characteristics to have a high alcohol level, a pleasant aroma, a weak acid taste, a pungent smell and a strong smell. These microorganisms differ from each other by the characteristics observed; which would 
indicate that the 5 strains obtained would constitute 5 different ferments. These different strains obtained are the dominant strains in palm wine because during palm exploitation all palm wines have pleasant aromas.

In conclusion, this study has shown that the physicochemical and microbiological parameters of the different Dura and Pisifera oil palm sap vary during the treatment time. The microbial load of palm wine varies during its exploitation. During this operation, microorganisms transform sugars into ethanol and organic acids. The heat treatment time plays an important role in the elimination of microorganisms in palm wine. The total elimination of microorganisms in the wine is observed after 3 minutes of heat treatment. Also, the physicochemical parameters (total sugars, reducing sugars and vitamin C) decrease during the heat treatment time. Aclear improvement must be made to the operating conditions to avoid an alteration of its physicochemical properties by microorganisms. The presence of useful microorganisms obtained after the panel in the different palm wines could have a beneficial effect for the industry, on the health of the consumer and thus increase the interest of this drink.

\section{References}

Amoa-Awua, W.K., Sampson, E. and TanoDebrah, K., 2007. Growth of yeasts, lactic and acetic bacteria in palm wine during tapping and fermentation from felled oil palm (Elaeis guineensis) in Ghana. Journal of Applied Microbiology. 102, 599-606.

Awasum, N.F., 2012. The Emergence of Public Spheres in Colonial Cameroon: Palm WineDrinking Joints in Bamenda Township. Afr Dev,38: 6984.
Bernfeld, D., 1955. Amylases, Alpha and Beta. In: Colowick, S.P. and Kaplan, N.O., Eds., Methods in Enzymology, Academic Press Inc., New York, 149154.

Danmadami, R.N., Yabaya, A., Yahaya, O., Abraham, O. J., Bobai, M., Orukotan, A. A., 2017. The efficiency of saccahromyces cerevisiae strain isolated from palm wine in the production of burukutu. Department of Microbiology, Kaduna State University, Kaduna, Nigeria Vol.5 (Iss.11); International Journal of Researche Granthaalyah. pp.72-85.

Dubois, M., Gilles, K., Hamilton, J. K., Rebers, P. A. and Smith, F., 1956. Colometric method for determinations of sugars and related substances. Anal. Chem., 280: 350-356.

Karamoko, D., Djeni, N. T., N'guessan, K. F., Bouatenin, K. M. J-P. and Dje, K. M., 2012. The biochemical and microbiological quality of palm wine samples produced at different periods during tapping and changes which occured during their storage. Food Control. 26: 504-511.

Kouchade, B.C., Kounouhewa, B., Awokou, S. K., 2017. La récolte de vin de palme: procédéet effets des conditions environnementales. Laboratoire de physique, faculté des sciences et techniques, UAC 01 BP4521 Cotonou, Bénin.OCL 24(5): D(505); p. 8.

Mehedi, H., 2018. Physiochemical, microbial and functional characteristics of Palmyra palm sap and pulp powder. MS Student Reg. Department of Agro processing. Bangabandhu Sheikh Mujibur Rahman Agricultural University Salna, Gazipur. p. 34.

Naknean, P., Meenune, M. and Roudaut, G., 2010. Characterization of palm sap arvested in Songkhla province, Southern Thailand. International Food 
Research Journal. 17, 977-986.

Ouoba, L., Kando, C., Parkouda, C., Sawadogo-Lingani, H., Diawara, B. and Sutherland, J. P. 2012. The microbiology of Bandji, palm wine of Borassus akeassii from Burkina Faso: identification and genotypic diversity of yeasts, lactic acid andacetic acid bacteria. Journal of Applied Microbiology 113(6): 1428-144.

Tapsoba, A., savadogo, A., Somda, K. M., Zongo, C., Barro, N., et, Traoré, S. A., 2011. Biodiversité microbienne et paramètres physicochimiques de quelques vins de rônier (Borassus Akeassi) produits traditionnellement au Burkina Faso. Rev.Microbiol.indsan et Evironn. Vol5 N². pp. 1-22.
Santiago-Urbina, J.A., Verdugo-Valdez, A. G. and Ruíz-Terán, F., 2013. Physicochemical and microbiological changes during tapping of palm sap to produce an alcoholic beverage called "Taberna" which is produced in the south east of Mexico. Food Control 33(1): 58-62.

Stringini, M., Comitini, F., Taccari, M. and Ciani, M., 2009. Yeast diversity during tapping and fermentation of palm wine from Cameroon. Food Microbiology 26 (4): 415-420.

Ukhum, M. E., Okolie, N. P., Oyerinde, A. O., 2005. Some mineral profiles of fresh and bottled palm wine a comparative study. Afr J. Biotechnol, 4: 829-832.

\section{How to cite this article:}

Karamoko Detto, Moroh Jean-Luc Aboya, Kokora Aya Philomène, Kouaho Frederic Harding and Dje Koffi Marcellin. 2019. Analysis of Physicochemical Parameters and Screening of Microorganisms to Formulate Ferments from Oil Palm Sap (Elaeis guineensis) in the Korhogo Area. Int.J.Curr.Microbiol.App.Sci. 8(08): 3005-3013. doi: https://doi.org/10.20546/ijcmas.2019.808.348 